\title{
Study of Seasonal Variation of Water Quality of River Siang in Arunachal Pradesh, India
}

\author{
Biplab Kumar Das ${ }^{1 *}$, Prasanna Boruah ${ }^{2}$ and Devashish Kar $^{3}$ \\ Department of Life Science and Bioinformatics, Assam University, Silchar- 788011, Assam, India. \\ Assam Remote Sensing Application Centre and Assam Science Technology and Environmental Council, \\ Guwahati -781005. Assam, India. \\ Department of Life Science and Bioinformatics and School of Life Sciences, Assam University, Silchar-788011, \\ Assam, India.
}

\begin{abstract}
Growing populations may put stresses on natural waters both the quality of the water and hydrological budget. River Siang is the main river of East Siang district and also it is one of the most important tributary of the mighty River Brahmaputra drainage system. Potable quality of river water is affected by seasons and other factors. Assessments of physico-chemical parameters were carried out during July 2012 to June 2013 in the six different study sites of River Siang. Twenty (20) different water quality parameters were measured in all collected samples, including Water Colour, Air Temperature, Water Temperature, pH, DO, $\mathrm{FCO}_{2}$, Conductivity, Total alkalinity, Turbidity, total hardness, TSS, TDS, Calcium, Magnesium, Sulphate, Chloride, Iron, Sodium, Manganese, Zinc. The results that are recorded in the different stations are compared with the World Health Organization (WHO) [1] and it was found that the water of River Siang may be suitable for drinking and domestic purposes because all the values are between WHO ; except the values of Iron.
\end{abstract}

Keywords: Seasonal Variations, River Siang, Physico-chemical parameters, Arunachal Pradesh, WHO.

\section{Introduction}

Water is the most vital resources for all kinds of life on this planet. Water is one of the nature's most important gifts to mankind. It is essential and most precious commodity for life. Rivers are vital and vulnerable freshwater systems and are essential for the sustenance of all life. The entire territory of Arunachal Pradesh forms a complex hill system with varying elevation, traveled throughout by a number of rivers and rivulets [3]. The unique drainage system of the state falls under upper Brahmaputra basins. Rivers provides main water resources for domestic, industrial and agricultural purposes [4]. The modern civilization, urbanization and prolonged discharge of industrial effluents, domestic sewage and solid waste dump cause the water to became polluted. Wild and domestic animals using same drinking water can also contaminate the water through direct defection and urination [2]. Variation in the quality and quantity of river is widely studied by the many researcher; Riedel et al. [5] examined the spatial-temporal variation in trace elements in Patuxent River, Maryland while Sileika, et al., [6] reported the variations in nutrient level in the Nemunas river of Russia. Schaefer and Alber [7] studied nitrogen and phosphorous in Altamaha river, Georgia. Singh, et al., [8] studied Physico-chemical properties of water samples from Manipur River System, India. Khatoon, et al., in [9] analyzed seasonal variation in the water quality among different ghats of river Ganga, Kanpur, India.

The present study is an attempt to characterize the trends in physico-chemical properties of water quality of River Siang in Arunachal Pradesh, India and compare the results with WHO standards.

\section{Study Site}

\section{Material And Methods}

The River Siang, is largest river of Brahmaputra river system, originates from Chema Yungdung Glacier near Kubi at $5150 \mathrm{~m}$ in Tibet. In Tibet it is popularly known as Tsang-Po, flows in West-East direction. After traversing a distance of about $1625 \mathrm{~km}$ river in Tibet and then it takes a turn in south direction, enters the territory of India near Tuting in the Upper Siang district of Arunachal Pradesh and flows through North-South direction in East Siang district towards Assam. In East Siang district the river flows as Siang and travels about $52 \mathrm{~km}$ from Pasighat at the foothills of the Himalayas and finally it merges with Lohit and Dibang in Assam and it becomes the mighty River Brahmaputra. 


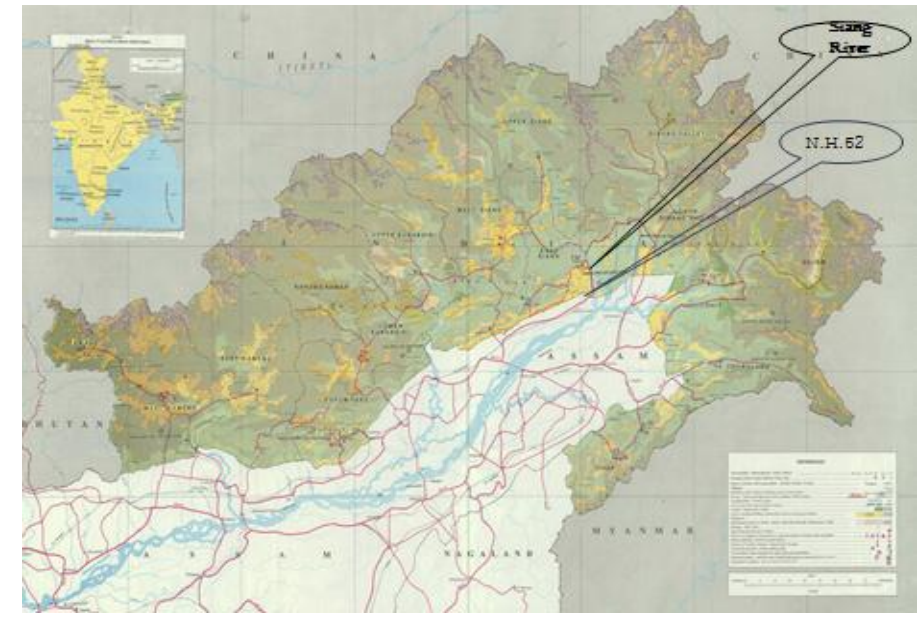

Fig I: Map Showing the Location of River Siang in Arunachal Pradesh

In the present study, water quality of River Siang is reported from six different portion of the river namely Mebo, Bodag, Ranahat, Pasighat, Ponging, and Rottang. The selection of the location is based the upstream, mid-stream and downstream of the River Siang. The samples were collected from six different sites during Monsoon, Post-Monsoon, Winter and Pre-Monsoon for the period since July 2012 to June 2013.

Table I: Habitat Characteristics of Siang River

\begin{tabular}{|c|c|c|c|c|c|c|}
\hline \multicolumn{7}{|c|}{ Habitat Characteristics } \\
\hline $\begin{array}{c}\text { Stream } \\
\text { Order }\end{array}$ & $\begin{array}{l}\text { Microhabitat } \\
\text { Type }\end{array}$ & Cover Type & $\begin{array}{c}\text { Substrate } \\
\text { Type }\end{array}$ & Riparian Land Use & $\begin{array}{l}\text { Signs of } \\
\text { Erosion }\end{array}$ & $\begin{array}{c}\text { Valley } \\
\text { Segment }\end{array}$ \\
\hline $\begin{array}{c}\text { First } \\
\text { Order }\end{array}$ & Riffle, Cascade, & $\begin{array}{l}\text { Under cut bedrock, } \\
\text { Overhanging, Depth, } \\
\text { Turbulence Cover, } \\
\text { Small Woody Debris. }\end{array}$ & $\begin{array}{l}\text { Boulders } \\
\text { Cobbles, } \\
\text { Gravels and } \\
\text { Fine Sands }\end{array}$ & $\begin{array}{lr}\text { Human } & \text { Habitation, } \\
\text { Fishing, } & \text { Protected } \\
\text { Areas as } & \text { Reserved } \\
\text { Forest } & \text { and } \\
\text { Agricultural Use } & \end{array}$ & Visible & Colluvial \\
\hline
\end{tabular}

Water was collected and stored in clean polyethylene bottles that have been pre washed with deionized water. Water colour, air temperature, water temperature and $\mathrm{pH}$ were determined in the field because of their unstable nature. Water temperature and air temperature were measured with the help of mercury thermometer and $\mathrm{pH}$ was measured with pen type $\mathrm{pH}$ meter in the field and other parameters was analyzed in the laboratory using standard procedure of APHA [10] and using Perkin Elmer Atomic Absorption Spectrophotometer (AAS).

\section{Results And Discussion}

The present study of physico-chemical parameters of the River Siang revealed the below mentioned parameters and the parameters are discussed in the below:

1. Water Colour: Colour change is not harmful unless it is associated with a toxic chemical but it may be affect the quality of sunlight that penetrates to a given depth inhibiting plant and animal metabolism. The colour of water colour was clear in most of the study sites but the colour is pale green in the mid-stream of the river.

2. Air Temperature: The value of air temperature is highest in summer season in the Ranaghat, 35 degree Celsius and minimum in the winter season in Ranaghat 21 degree Celsius.

3. Water Temperature: The value of water temperature is highest in Pasighat (summer) 30 degree Celsius and minimum in Mebo (winter) 15 degree Celsius.

4. $\mathbf{p H}$ : The $\mathrm{pH}$ of a water body is very important in determination of water quality since it affects other chemical reactions such as solubility and metal toxicity, [11]. During the present study the value of $\mathrm{pH}$ is found normal in every portion of the river; the total ranges of value is lies between 6 to 8 . The highest value of $\mathrm{pH}$ was recorded as 7.91 in Post-Monsoon season at Rottang and the minimum recoded as 6.3 in winter season at Ponging.

5. Dissolved Oxygen: Dissolved Oxygen (DO) is an important limnological parameter indicating level of water quality and organic pollution in the water body, [12]. The value of DO is remarkably significant in determining the water quality criteria of an aquatic system, [9]. In the system where the rates respiration and organic decomposition are high, the DO values usually remain lower than those of the system, where the rate of photosynthesis is high, [3]. The maximum value of DO is recorded as $8.8 \mathrm{mg} / \mathrm{L}$ in summer at Rottang and minimum recorded in minimum recorded as 4.9 in Pre-Monsoon at Ranaghat. The maximum DO value in Monsoon (summer) is due to bright sunlight as it influences the \% of soluble gases. The long 
day period of high intensity of sunlight accelerated photosynthesis which resulted to increase DO in summer, [13].

6. Free Carbon-di-oxide: Free carbon-di-oxide $\left(\mathrm{FCO}_{2}\right)$ dissolves in water varying amounts and the dissolution depends on partial pressure and temperature. $\mathrm{FCO}_{2}$ plays an important role in water bodies by producing calcium bicarbonate from calcium carbonate and this gas alters the $\mathrm{pH}$ of water by reacting with it to form carbonic acid. It is the basic raw material of photosynthesis in aquatic ecosystems[14]. At low dissolved oxygen concentration, presence of high $\mathrm{FCO}_{2}$ hinders oxygen uptake. The value of $\mathrm{FCO}_{2}$ ranges between 3.4 to $7.1 \mathrm{mg} / \mathrm{L}$. The value was minimum in winter at Ponging while it was recorded as high also in Ponging in post-monsoon season.

7. Conductivity: Conductivity measures the capacity of water to convey electric current. Conductivity of water varies directly with the temperature and it is proportional to its dissolved mineral matter content. The value of conductivity ranges between 7-14 ppm. The value highest at Bodag and the lowest value in Mebo of River Siang.

8. Total Alkalinity: The value of total alkalinity (TA) provides idea of natural salts present in water, Gawas $e t$ al., 2006. Natural waters with high alkalinity are generally rich in phytoplankton, especially the blue greens. It is an important factor for productivity of an aquatic ecosystem. Total alkalinity of water is mainly caused by the cations $\mathrm{Ca}, \mathrm{Mg}, \mathrm{Na}, \mathrm{K}, \mathrm{NH}_{4}$ and $\mathrm{Fe}$ in combination with either $\mathrm{CO}_{3}{ }^{2-}$ or $\mathrm{HCO}_{3}{ }^{-}$or occasionally as $\mathrm{OH}^{-}$. Total alkalinity of water is due presence of mineral salts in it [14]. It is primarily caused by the carbonate and bicarbonate ions [8], [9].

9. Turbidity: Turbidity is the material in water that affects the transparency or light scattering of the water. The observed values of the turbidity were within the limit range of WHO standards. The minimum values were recorded at Bodag as 78.1 and maximum values were recorded at Rottang as 99.9. The both minimum and maximum values were recorded in in pre-monsoon season.

10. Total Hardness: Hardness is the property of water which prevents the lather formation with soap and increases the boiling point of the waters. The major cations imparting hardness are calcium and magnesium. Therefore, the total hardness of water is defined as the summary concentration of calcium and magnesium cations. The anions responsible for hardness are bicarbonate, carbonate, Sulphate and chlorides. Hardness is temporary if it is associated mainly with carbonates and bicarbonates. The value of total hardness is maximum in winter recorded as $88.5 \mathrm{mg} / \mathrm{L}$ at Bodag and minimum in pre-monsoon recorded as 64.7 at Mebo of river Siang.

11. Total Suspended Solids: Total Suspended Solids (TSS) varied from $101.8 \mathrm{mg} / \mathrm{L}$ to $129.3 \mathrm{mg} / \mathrm{L}$. the maximum value was observed at Ranaghat in winter season and minimum value was recorded at Bodag in Pre-Monson season. The both minimum and maximum values are in the WHO standards. TSS is typically composed of fine clay or silt particles, plankton, organic compounds, inorganic compounds or other microorganisms.

12. Total Dissolved Solids: The quality of the Total Dissolved Solids (TDS) is in general proportional to the degree of pollution. TDS of the water sample varied from $4 \mathrm{ppm}$ to $9 \mathrm{ppm}$ which is below the permissible limits of WHO standards. The maximum value at Pasighat and the minimum value were recorded at Bodag. The value of TDS is higher in Monsoon seasons than that of winter and other seasons. TDS can be influenced by changes in $\mathrm{pH}$. Changes in the $\mathrm{pH}$ will cause some of the solutes to precipitate or will affect the solubility of the suspended matter [15].

13. Calcium: Calcium is an important micronutrient in an aquatic environment and this environment is affected by adsorption of calcium ion on the metallic oxides. In addition to this it has effect of microorganisms, which play an important role in calcium exchange between sediments and overlaying water [16]. The value of Calcium is ranges between 51.0 to $70.1 \mathrm{mg} / \mathrm{L}$. The lowest value is recorded at Ponging in monsoon season and the high value is recorded at Rottang in winter season. The both minimum and maximum permissible values are in the WHO standards.

14. Magnesium: Magnesium is essential for chlorophyll and acts as a limiting factor for the growth of phytoplankton. Therefore depletion of magnesium reduces the phytoplankton population. Magnesium is required as an essential nutrient for aquatic plants [17]. Concentration of magnesium up-to 30ppm is recommended for drinking waters [14]. The value of Magnesium is ranges between 8.9 to $18.15 \mathrm{mg} / \mathrm{L}$. The lowest value is recorded at Rottang in monsoon season and the high value is recorded at Rottang in premonsoon season. The both minimum and maximum permissible values are in the WHO standards.

15. Sulphate: The value of Sulphate ranges between 1.02 to $7.85 \mathrm{mg} / \mathrm{L}$. The lowest value is recorded at Bodag in post- monsoon season and the high value is recorded at Rottang in pre-monsoon season. The both minimum and maximum permissible values are in the WHO standards.

16. Chloride: The origin of chloride is mostly from weathering of rocks but pollution can contribute locally. As chlorine is the main source of chloride, so by measuring the chloride one can easily identify he pollute water [18]. The value of Chloride is ranges between 2.12 to $12.50 \mathrm{mg} / \mathrm{L}$. The lowest value is recorded at 
Mebo in monsoon season and the high value is recorded at Rottang in winter season. The both minimum and maximum permissible values are in the WHO standards.

17. Iron: The value of Iron is ranges between 1.61 to $6.74 \mathrm{mg} / \mathrm{L}$. The lowest value is recorded at Mebo in premonsoon season and the high value is recorded at Ranaghat in monsoon season. The both minimum and maximum values are cross the limits of WHO standards.

18. Sodium: The value of Sodium is ranges between 1.23 to $6.78 \mathrm{mg} / \mathrm{L}$. The lowest value is recorded at Mebo in winter season and the high value is recorded at Rottang in pre-monsoon season. The both minimum and maximum permissible values are in the WHO standards.

19. Manganese: The value of Manganese is ranges between 0.1 to $0.11 \mathrm{mg} / \mathrm{L}$. The both minimum and maximum values are cross the limits of WHO standards. The WHO standard limit value of Manganese is 0.1 .

20. Zinc: The value of Zinc is ranges between 0.01 to $1.91 \mathrm{mg} / \mathrm{L}$. Most of the values that were recorded in the River Siang were lies between 0.01 to 0.10 ; but exceptionally in the pre-monsoon season at Rottang the value was recorded as then 1.91 , but both the minimum and maximum permissible values are in the WHO standards.

\begin{tabular}{|c|c|c|c|c|c|c|c|c|c|}
\hline \multirow{2}{*}{$\begin{array}{l}\mathbf{S} \\
\mathbf{L} \\
\mathbf{N} \\
\mathbf{O}\end{array}$} & \multirow{2}{*}{$\begin{array}{l}\text { PARAMETE } \\
\text { RS }\end{array}$} & \multicolumn{6}{|c|}{ STUDY SITE (MONSOON) } & \multirow{2}{*}{$\begin{array}{l}\text { AVERA } \\
\text { GE }\end{array}$} & \multirow{2}{*}{$\begin{array}{c}\text { WHO } \\
\text { STAND } \\
\text { ARDS }\end{array}$} \\
\hline & & МЕBО & BODAG & $\begin{array}{l}\text { RANAGH } \\
\text { AT }\end{array}$ & PASIGHAT & PONGING & $\begin{array}{c}\text { ROTTAN } \\
\text { G }\end{array}$ & & \\
\hline 1 & Water Colour & Clear & $\begin{array}{l}\text { Transpare } \\
\text { nt white }\end{array}$ & Pale Green & Pale Green & Clear & $\begin{array}{l}\text { Light } \\
\text { Copper } \\
\text { Red }\end{array}$ & - & N/A \\
\hline 2 & $\begin{array}{c}\text { Air } \\
\text { Temperature } \\
\mathbf{C}^{\mathbf{0}}\end{array}$ & 25 & 23 & 35 & 34 & 33 & 31 & 30.17 & N/A \\
\hline 3 & $\begin{array}{c}\text { Water } \\
\text { Temperature } \\
\text { C }^{0}\end{array}$ & 26 & 26 & 27 & 30 & 28 & 27 & 27.33 & N/A \\
\hline 4 & pH & 6.8 & 6.6 & 7.12 & 7.56 & 7.3 & 7.11 & 7.08 & 6.5-8.5 \\
\hline 5 & DO (mg/l) & 7.7 & 7.6 & 7.9 & 8.3 & 7.9 & 8.8 & 8.03 & 5-8 \\
\hline 6 & $\mathrm{FCO}_{2}(\mathrm{mg} / \mathrm{l})$ & 5.2 & 5.4 & 5.5 & 5.7 & 4.4 & 6.1 & 5.38 & $\begin{array}{c}22 \\
(\mathrm{Max})\end{array}$ \\
\hline 7 & $\begin{array}{c}\text { Conductivity } \\
\text { (ppm) }\end{array}$ & 7 & 9 & 12 & 11 & 10 & 9 & 9.67 & N/A \\
\hline 8 & $\begin{array}{c}\text { Total } \\
\text { Alkalinity } \\
\text { Methyl } \\
\text { Orange } \\
(\mathrm{mg} / \mathrm{l}) \\
\end{array}$ & 68.1 & 69.8 & 70.8 & 74.5 & 73.7 & 72.8 & 71.62 & $\begin{array}{c}200 \\
\text { (Max) }\end{array}$ \\
\hline 9 & $\begin{array}{l}\text { Turbidity } \\
\text { (NTU) }\end{array}$ & 90.1 & 92.1 & 90.1 & 90.6 & 92.9 & 94.9 & 91.78 & $\begin{array}{c}10 \\
(\text { Max })\end{array}$ \\
\hline 10 & $\begin{array}{c}\text { Total } \\
\text { Hardness } \\
(\mathrm{mg} / \mathrm{l}) \\
\end{array}$ & 66.7 & 68.5 & 68.2 & 69.8 & 65.4 & 69.9 & 68.08 & $\begin{array}{c}300 \\
\text { (Max) }\end{array}$ \\
\hline 11 & TSS (mg/l) & 107.8 & 111.8 & 109.8 & 106.6 & 105.4 & 115.9 & 109.55 & $\begin{array}{c}\mathbf{5 0 0} \\
(\mathbf{M a x})\end{array}$ \\
\hline 12 & TDS (ppm) & 5 & 4 & 7 & 9 & 4 & 6 & 5.83 & $250-600$ \\
\hline 13 & $\begin{array}{c}\text { Calcium } \\
(\mathrm{mg} / \mathrm{l})\end{array}$ & 51.8 & 53.5 & 52.0 & 54.6 & 51.0 & 50.6 & 52.25 & $\begin{array}{c}75 \\
(\text { Max) }\end{array}$ \\
\hline 14 & $\begin{array}{c}\text { Magnesium } \\
(\mathrm{mg} / \mathrm{l})\end{array}$ & 10.9 & 11.6 & 13.4 & 12.6 & 15.7 & 8.9 & 12.18 & $\begin{array}{c}\text { 30 } \\
\text { (Max) }\end{array}$ \\
\hline 15 & $\begin{array}{c}\text { Sulphate } \\
(\mathrm{mg} / \mathrm{l})\end{array}$ & 2.07 & 2.02 & 1.98 & 4.56 & 1.98 & 1.80 & 2.4 & $\begin{array}{c}150 \\
\text { (Max) }\end{array}$ \\
\hline 16 & $\begin{array}{c}\text { Chloride } \\
(\mathrm{mg} / \mathrm{l})\end{array}$ & 2.12 & 2.34 & 5.6 & 4.5 & 7.89 & 6.78 & 4.87 & $\begin{array}{c}250 \\
(\operatorname{Max})\end{array}$ \\
\hline 17 & Iron (mg/l) & 3.56 & 4.56 & 6.74 & 4.23 & 4.67 & 3.45 & 4.53 & $\begin{array}{c}\mathbf{0 . 3} \\
(\mathrm{Max})\end{array}$ \\
\hline 18 & Sodium (mg/l) & 1.34 & 2.34 & 2.54 & 2.13 & 2.32 & 2.34 & 2.17 & $\begin{array}{c}200 \\
(\operatorname{Max})\end{array}$ \\
\hline 19 & Manganese & 0.1 & 0.2 & 0.2 & 0.4 & 0.6 & 0.11 & 0.27 & 0.1 \\
\hline
\end{tabular}


Study of Seasonal Variation of Water Quality of River Siang in Arunachal Pradesh, India

\begin{tabular}{|c|c|c|c|c|c|c|c|c|c|}
\hline & $(\mathrm{mg} / \mathrm{l})$ & & & & & & & & (Max) \\
\hline 20 & Zinc (mg/l) & 0.01 & 0.03 & 0.05 & 0.07 & 0.04 & 0.04 & 0.04 & $\begin{array}{c}\mathbf{5 . 0} \\
(\mathbf{M a x})\end{array}$ \\
\hline
\end{tabular}

\begin{tabular}{|c|c|c|c|c|c|c|c|c|c|}
\hline \multirow{2}{*}{$\begin{array}{l}\mathbf{S} \\
\mathbf{L} \\
\mathbf{N} \\
\mathbf{O}\end{array}$} & \multirow{2}{*}{$\begin{array}{l}\text { PARAMETE } \\
\text { RS }\end{array}$} & \multicolumn{6}{|c|}{ STUDY SITE (POST-MONSOON) } & \multirow{2}{*}{$\begin{array}{l}\text { AVERA } \\
\text { GE }\end{array}$} & \multirow{2}{*}{$\begin{array}{c}\text { WHO } \\
\text { STAND } \\
\text { ARDS }\end{array}$} \\
\hline & & МEBO & BODAG & $\begin{array}{l}\text { RANAG } \\
\text { HAT }\end{array}$ & $\begin{array}{c}\text { PASIGHA } \\
\text { T }\end{array}$ & $\begin{array}{l}\text { PONGIN } \\
\text { G }\end{array}$ & $\begin{array}{l}\text { ROTTA } \\
\text { NG }\end{array}$ & & \\
\hline 1 & $\begin{array}{l}\text { Water } \\
\text { Colour }\end{array}$ & $\begin{array}{l}\text { Transpar } \\
\text { ent white }\end{array}$ & $\begin{array}{l}\text { Transpar } \\
\text { ent white }\end{array}$ & $\begin{array}{c}\text { Pale } \\
\text { Green }\end{array}$ & Pale Green & Clear & $\begin{array}{l}\text { Light } \\
\text { Copper } \\
\text { Red }\end{array}$ & - & N/A \\
\hline 2 & $\begin{array}{c}\text { Air } \\
\text { Temperature } \\
\text { C }^{0}\end{array}$ & 22 & 23 & 25 & 24 & 23 & 27 & 24 & $\mathbf{N} / \mathbf{A}$ \\
\hline 3 & $\begin{array}{c}\text { Water } \\
\text { Temperature } \\
\text { C }^{0}\end{array}$ & 21 & 22 & 24 & 23 & 22 & 24 & 22.67 & N/A \\
\hline 4 & pH & 6.7 & 6.9 & 7.52 & 7.76 & 7.3 & 7.91 & 7.35 & 6.5-8.5 \\
\hline 5 & DO (mg/l) & 5.7 & 6.6 & 4.9 & 5.3 & 6.9 & 7.8 & 6.2 & $5-8$ \\
\hline 6 & $\mathrm{FCO}_{2}(\mathrm{mg} / \mathrm{l})$ & 4.2 & 5.8 & 5.8 & 5.9 & 4.9 & 7.1 & 5.62 & $\begin{array}{c}22 \\
(\text { Max) }\end{array}$ \\
\hline 7 & $\begin{array}{c}\text { Conductivity } \\
\text { (ppm) }\end{array}$ & 8 & 10 & 11 & 11 & 13 & 10 & 10.5 & N/A \\
\hline 8 & $\begin{array}{c}\text { Total } \\
\text { Alkalinity } \\
\text { Methyl } \\
\text { Orange } \\
\text { (mg/l) }\end{array}$ & 64.1 & 65.8 & 77.8 & 73.5 & 72.7 & 68.8 & 70.45 & $\begin{array}{c}200 \\
(\text { Max })\end{array}$ \\
\hline 9 & $\begin{array}{l}\text { Turbidity } \\
\text { (NTU) }\end{array}$ & 88.1 & 78.1 & 97.1 & 91.6 & 85.9 & 99.9 & 90.12 & $\begin{array}{c}10 \\
(\mathrm{Max})\end{array}$ \\
\hline $\begin{array}{l}1 \\
0\end{array}$ & $\begin{array}{c}\text { Total } \\
\text { Hardness } \\
(\mathrm{mg} / \mathrm{l})\end{array}$ & 69.7 & 68.5 & 66.2 & 65.8 & 67.4 & 68.9 & 67.75 & $\begin{array}{c}300 \\
(\text { Max })\end{array}$ \\
\hline $\begin{array}{l}1 \\
1\end{array}$ & TSS (mg/l) & 101.8 & 107.8 & 102.8 & 104.6 & 107.4 & 110.9 & 105.89 & $\begin{array}{c}\mathbf{5 0 0} \\
(\mathrm{Max})\end{array}$ \\
\hline $\begin{array}{l}1 \\
2\end{array}$ & TDS (ppm) & 4 & 5 & 9 & 8 & 5 & 9 & 6.67 & $250-600$ \\
\hline $\begin{array}{l}1 \\
3\end{array}$ & $\begin{array}{c}\text { Calcium } \\
(\mathrm{mg} / \mathrm{l})\end{array}$ & 56.8 & 52.5 & 53.0 & 57.6 & 57.7 & 52.6 & 55.03 & $\begin{array}{c}75 \\
(\text { Max })\end{array}$ \\
\hline $\begin{array}{l}1 \\
4\end{array}$ & $\begin{array}{c}\text { Magnesium } \\
(\mathrm{mg} / \mathrm{l})\end{array}$ & 11.9 & 17.6 & 14.4 & 11.6 & 13.7 & 10.9 & 13.35 & $\begin{array}{c}30 \\
(\mathrm{Max})\end{array}$ \\
\hline $\begin{array}{l}1 \\
5\end{array}$ & $\begin{array}{c}\text { Sulphate } \\
(\mathrm{mg} / \mathrm{l})\end{array}$ & 1.07 & 1.02 & 2.98 & 3.56 & 1.68 & 1.189 & 1.91 & $\begin{array}{c}150 \\
\text { (Max) }\end{array}$ \\
\hline $\begin{array}{l}1 \\
6 \\
\end{array}$ & $\begin{array}{c}\text { Chloride } \\
(\mathrm{mg} / \mathrm{l})\end{array}$ & 2.22 & 2.44 & 5.78 & 4.15 & 7.19 & 4.78 & 4.42 & $\begin{array}{c}250 \\
(\mathrm{Max})\end{array}$ \\
\hline $\begin{array}{l}1 \\
7\end{array}$ & Iron (mg/l) & 3.36 & 4.58 & 5.64 & 2.21 & 4.68 & 2.45 & 3.82 & $\begin{array}{c}0.3 \\
(\operatorname{Max})\end{array}$ \\
\hline $\begin{array}{l}1 \\
8\end{array}$ & $\begin{array}{c}\text { Sodium } \\
(\mathrm{mg} / \mathrm{l})\end{array}$ & 1.24 & 2.23 & 2.64 & 2.34 & 2.72 & 2.04 & 2.2 & $\begin{array}{c}200 \\
(\operatorname{Max})\end{array}$ \\
\hline $\begin{array}{l}1 \\
9 \\
\end{array}$ & $\begin{array}{c}\text { Manganese } \\
(\mathrm{mg} / \mathrm{l})\end{array}$ & 0.1 & 0.1 & 0.3 & 0.2 & 0.6 & 0.9 & 0.37 & $\begin{array}{c}0.1 \\
(\text { Max })\end{array}$ \\
\hline $\begin{array}{l}2 \\
0\end{array}$ & Zinc (mg/l) & 0.01 & 0.02 & 0.05 & 0.08 & 0.01 & 0.07 & 0.04 & $\begin{array}{c}5.0 \\
(\mathbf{M a x})\end{array}$ \\
\hline
\end{tabular}

\begin{tabular}{|c|c|c|c|c|c|c|c|c|c|}
\hline \multirow{2}{*}{$\begin{array}{l}\mathbf{S} \\
\mathbf{L} \\
\mathbf{N} \\
\mathbf{O}\end{array}$} & \multirow{2}{*}{$\begin{array}{l}\text { PARAMETE } \\
\text { RS }\end{array}$} & \multicolumn{6}{|c|}{ STUDY SITE (WINTER) } & \multirow{2}{*}{$\begin{array}{l}\text { AVERA } \\
\text { GE }\end{array}$} & \multirow{2}{*}{$\begin{array}{c}\text { WHO } \\
\text { STAND } \\
\text { ARDS }\end{array}$} \\
\hline & & MEBO & BODAG & $\begin{array}{c}\text { RANAGH } \\
\text { AT }\end{array}$ & PASIGHAT & PONGING & $\begin{array}{c}\text { ROTTAN } \\
\text { G }\end{array}$ & & \\
\hline 1 & Water Colour & Clear & Clear & Pale Green & $\begin{array}{c}\text { Light Copper } \\
\text { Red }\end{array}$ & $\begin{array}{c}\text { Blackish } \\
\text { White }\end{array}$ & $\begin{array}{c}\text { Copper } \\
\text { Red and } \\
\text { White Mix }\end{array}$ & - & $\mathbf{N} / \mathbf{A}$ \\
\hline
\end{tabular}


Study of Seasonal Variation of Water Quality of River Siang in Arunachal Pradesh, India

\begin{tabular}{|c|c|c|c|c|c|c|c|c|c|}
\hline 2 & $\begin{array}{c}\text { Air } \\
\text { Temperature } \\
C^{0} \\
\end{array}$ & 22 & 23 & 21 & 24 & 24 & 21 & 22.5 & N/A \\
\hline 3 & $\begin{array}{c}\text { Water } \\
\text { Temperature } \\
\text { C }^{0}\end{array}$ & 15 & 17 & 16 & 20 & 18 & 17 & 17.17 & N/A \\
\hline 4 & pH & 6.5 & 7.6 & 7.45 & 7.56 & 6.3 & 8.11 & 7.25 & $6.5-8.5$ \\
\hline 5 & DO (mg/l) & 6.7 & 6.6 & 6.9 & 6.3 & 5.9 & 5.8 & 6.34 & $5-8$ \\
\hline 6 & $\mathrm{FCO}_{2}(\mathrm{mg} / \mathrm{l})$ & 4.2 & 4.4 & 4.5 & 4.7 & 3.4 & 3.9 & 4.18 & $\begin{array}{c}22 \\
\text { (Max) }\end{array}$ \\
\hline 7 & $\begin{array}{c}\text { Conductivity } \\
\text { (ppm) }\end{array}$ & 12 & 14 & 13 & 15 & 16 & 15 & 14.17 & N/A \\
\hline 8 & $\begin{array}{c}\text { Total } \\
\text { Alkalinity } \\
\text { Methyl } \\
\text { Orange } \\
\text { (mg/l) }\end{array}$ & 78.1 & 79.8 & 75.8 & 75.5 & 74.7 & 79.8 & 77.28 & $\begin{array}{c}200 \\
(\text { Max })\end{array}$ \\
\hline 9 & $\begin{array}{c}\text { Turbidity } \\
\text { (NTU) }\end{array}$ & 92.1 & 92.1 & 93.1 & 94.7 & 96.5 & 99.8 & 94.72 & $\begin{array}{c}10 \\
(\mathrm{Max})\end{array}$ \\
\hline 10 & $\begin{array}{c}\text { Total } \\
\text { Hardness } \\
(\mathrm{mg} / \mathrm{l}) \\
\end{array}$ & 76.7 & 88.5 & 88.4 & 79.2 & 75.4 & 79.9 & 81.35 & $\begin{array}{c}300 \\
(\text { Max })\end{array}$ \\
\hline 11 & TSS (mg/l) & 116.9 & 121.7 & 129.3 & 126.1 & 125.9 & 125.3 & 124.2 & $\begin{array}{c}\mathbf{5 0 0} \\
(\mathrm{Max})\end{array}$ \\
\hline 12 & TDS (ppm) & 4 & 6 & 9 & 10 & 7 & 8 & 7.33 & $250-600$ \\
\hline 13 & $\begin{array}{c}\text { Calcium } \\
(\mathrm{mg} / \mathrm{l})\end{array}$ & 57.5 & 54.6 & 53.1 & 67.4 & 68.2 & 70.1 & 61.82 & $\begin{array}{c}75 \\
(\text { Max }) \\
\end{array}$ \\
\hline 14 & $\begin{array}{c}\text { Magnesium } \\
(\mathrm{mg} / \mathrm{l})\end{array}$ & 11.5 & 17.7 & 15.3 & 9.67 & 11.52 & 9.81 & 12.58 & $\begin{array}{c}30 \\
(\mathrm{Max})\end{array}$ \\
\hline 15 & $\begin{array}{c}\text { Sulphate } \\
(\mathrm{mg} / \mathrm{l})\end{array}$ & 1.17 & 3.32 & 1.76 & 3.76 & 3.88 & 3.90 & 2.97 & $\begin{array}{c}150 \\
(\text { Max })\end{array}$ \\
\hline 16 & $\begin{array}{c}\text { Chloride } \\
(\mathrm{mg} / \mathrm{l})\end{array}$ & 11.27 & 11.84 & 11.45 & 10.45 & 10.65 & 12.50 & 11.36 & $\begin{array}{c}250 \\
(\text { Max })\end{array}$ \\
\hline 17 & Iron (mg/l) & 3.06 & 2.06 & 4.98 & 5.28 & 5.60 & 5.65 & 4.44 & $\begin{array}{c}0.3 \\
(\text { Max }) \\
\end{array}$ \\
\hline 18 & Sodium (mg/l) & 1.23 & 3.44 & 3.94 & 4.56 & 1.45 & 4.98 & 3.37 & $\begin{array}{c}200 \\
(\text { Max })\end{array}$ \\
\hline 19 & $\begin{array}{c}\text { Manganese } \\
(\mathrm{mg} / \mathrm{l})\end{array}$ & 0.3 & 0.1 & 0.5 & 0.4 & 0.6 & 0.7 & 0.43 & $\begin{array}{c}\mathbf{0 . 1} \\
(\mathbf{M a x})\end{array}$ \\
\hline 20 & Zinc (mg/l) & 0.02 & 0.02 & 0.03 & 0.04 & 0.05 & 0.04 & 0.03 & $\begin{array}{c}5.0 \\
(\mathrm{Max})\end{array}$ \\
\hline
\end{tabular}

\begin{tabular}{|c|c|c|c|c|c|c|c|c|c|}
\hline \multirow{2}{*}{$\begin{array}{l}\mathbf{S} \\
\mathbf{L} \\
\mathbf{N} \\
\mathbf{O}\end{array}$} & \multirow{2}{*}{$\begin{array}{l}\text { PARAMETE } \\
\text { RS }\end{array}$} & \multicolumn{6}{|c|}{ STUDY SITE (PRE-MONSOON) } & \multirow{2}{*}{$\begin{array}{l}\text { AVERA } \\
\text { GE }\end{array}$} & \multirow{2}{*}{$\begin{array}{c}\text { WHO } \\
\text { STAND } \\
\text { ARDS }\end{array}$} \\
\hline & & MEBO & BODAG & $\begin{array}{c}\text { RANAGH } \\
\text { AT }\end{array}$ & PASIGHAT & PONGING & $\begin{array}{c}\text { ROTTAN } \\
\text { G }\end{array}$ & & \\
\hline 1 & Water Colour & Clear & Clear & Pale Green & Pale Green & Clear & $\begin{array}{l}\text { Light } \\
\text { Copper } \\
\text { Red }\end{array}$ & - & N/A \\
\hline 2 & $\begin{array}{c}\text { Air } \\
\text { Temperature } \\
\text { C }^{\mathbf{0}}\end{array}$ & 25 & 24 & 25 & 26 & 23 & 26 & 24.83 & N/A \\
\hline 3 & $\begin{array}{c}\text { Water } \\
\text { Temperature } \\
\text { C }^{\mathbf{0}}\end{array}$ & 22 & 22 & 24 & 26 & 24 & 28 & 24.33 & N/A \\
\hline 4 & pH & 6.4 & 6.6 & 7.1 & 6.56 & 6.3 & 6.91 & 6.65 & $6.5-8.5$ \\
\hline 5 & DO (mg/l) & 6.7 & 7.7 & 7.2 & 6.3 & 6.9 & 7.8 & 7.1 & 5-8 \\
\hline 6 & $\mathrm{FCO}_{2}(\mathrm{mg} / \mathrm{l})$ & 4.2 & 5.4 & 4.5 & 5.7 & 4.1 & 4.3 & 4.7 & 22 (Max) \\
\hline 7 & $\begin{array}{c}\text { Conductivity } \\
\text { (ppm) }\end{array}$ & 13 & 11 & 11 & 11 & 13 & 9 & 11 & N/A \\
\hline 8 & Total & 64.1 & 71.8 & 73.4 & 75.6 & 74.5 & 71.9 & 71.89 & 200 \\
\hline
\end{tabular}


Study of Seasonal Variation of Water Quality of River Siang in Arunachal Pradesh, India

\begin{tabular}{|c|c|c|c|c|c|c|c|c|c|}
\hline & $\begin{array}{c}\text { Alkalinity } \\
\text { Methyl } \\
\text { Orange } \\
\text { (mg/l) }\end{array}$ & & & & & & & & (Max) \\
\hline 9 & $\begin{array}{c}\text { Turbidity } \\
\text { (NTU) }\end{array}$ & 89.1 & 91.1 & 95.5 & 96.6 & 92.3 & 92.1 & 92.78 & $\begin{array}{c}100 \\
(\mathrm{Max}) \\
\end{array}$ \\
\hline 10 & $\begin{array}{c}\text { Total } \\
\text { Hardness } \\
(\mathrm{mg} / \mathrm{l})\end{array}$ & 64.7 & 65.5 & 67.2 & 64.8 & 66.4 & 70.1 & 66.45 & $\begin{array}{c}300 \\
(\text { Max })\end{array}$ \\
\hline 11 & TSS (mg/l) & 106.8 & 101.8 & 113.4 & 156.6 & 107.3 & 109.9 & 115.97 & $\begin{array}{c}\mathbf{5 0 0} \\
(\mathbf{M a x}) \\
\end{array}$ \\
\hline 12 & TDS (ppm) & 5 & 5 & 7 & 9 & 9 & 7 & 7 & $250-600$ \\
\hline 13 & $\begin{array}{c}\text { Calcium } \\
(\mathrm{mg} / \mathrm{l})\end{array}$ & 56.8 & 54.8 & 58.4 & 58.6 & 54.5 & 52.8 & 55.98 & 75 (Max) \\
\hline 14 & $\begin{array}{c}\text { Magnesium } \\
(\mathrm{mg} / \mathrm{l})\end{array}$ & 11.07 & 12.52 & 14.22 & 13.75 & 14.52 & 18.15 & 14.03 & 30 (Max) \\
\hline 15 & $\begin{array}{c}\text { Sulphate } \\
(\mathrm{mg} / \mathrm{l})\end{array}$ & 4.07 & 5.12 & 6.38 & 8.56 & 6.81 & 7.85 & 6.47 & $\begin{array}{c}150 \\
(\text { Max })\end{array}$ \\
\hline 16 & $\begin{array}{c}\text { Chloride } \\
(\mathrm{mg} / \mathrm{l})\end{array}$ & 10.02 & 8.14 & 5.61 & 2.17 & 9.19 & 8.98 & 7.36 & $\begin{array}{c}250 \\
(\text { Max })\end{array}$ \\
\hline 17 & Iron (mg/l) & 1.61 & 3.23 & 4.14 & 4.03 & 2.17 & 2.79 & 2.99 & $\begin{array}{c}0.3 \\
\text { (Max) } \\
\end{array}$ \\
\hline 18 & Sodium (mg/l) & 6.14 & 4.56 & 1.43 & 3.33 & 4.46 & 6.78 & 4.45 & $\begin{array}{c}200 \\
(\text { Max })\end{array}$ \\
\hline 19 & $\begin{array}{c}\text { Manganese } \\
(\mathrm{mg} / \mathrm{l})\end{array}$ & 0.1 & 0.1 & 0.1 & 0.3 & 0.4 & 0.2 & 0.2 & $\begin{array}{c}\mathbf{0 . 1} \\
(\operatorname{Max})\end{array}$ \\
\hline 20 & Zinc (mg/l) & 0.11 & 0.13 & 1.76 & 1.39 & 1.89 & 1.91 & 1.2 & $\begin{array}{c}5.0 \\
(\mathbf{M a x})\end{array}$ \\
\hline
\end{tabular}

\section{Table II: Physico-Chemical Parameters of Siang River in Different Seasons}
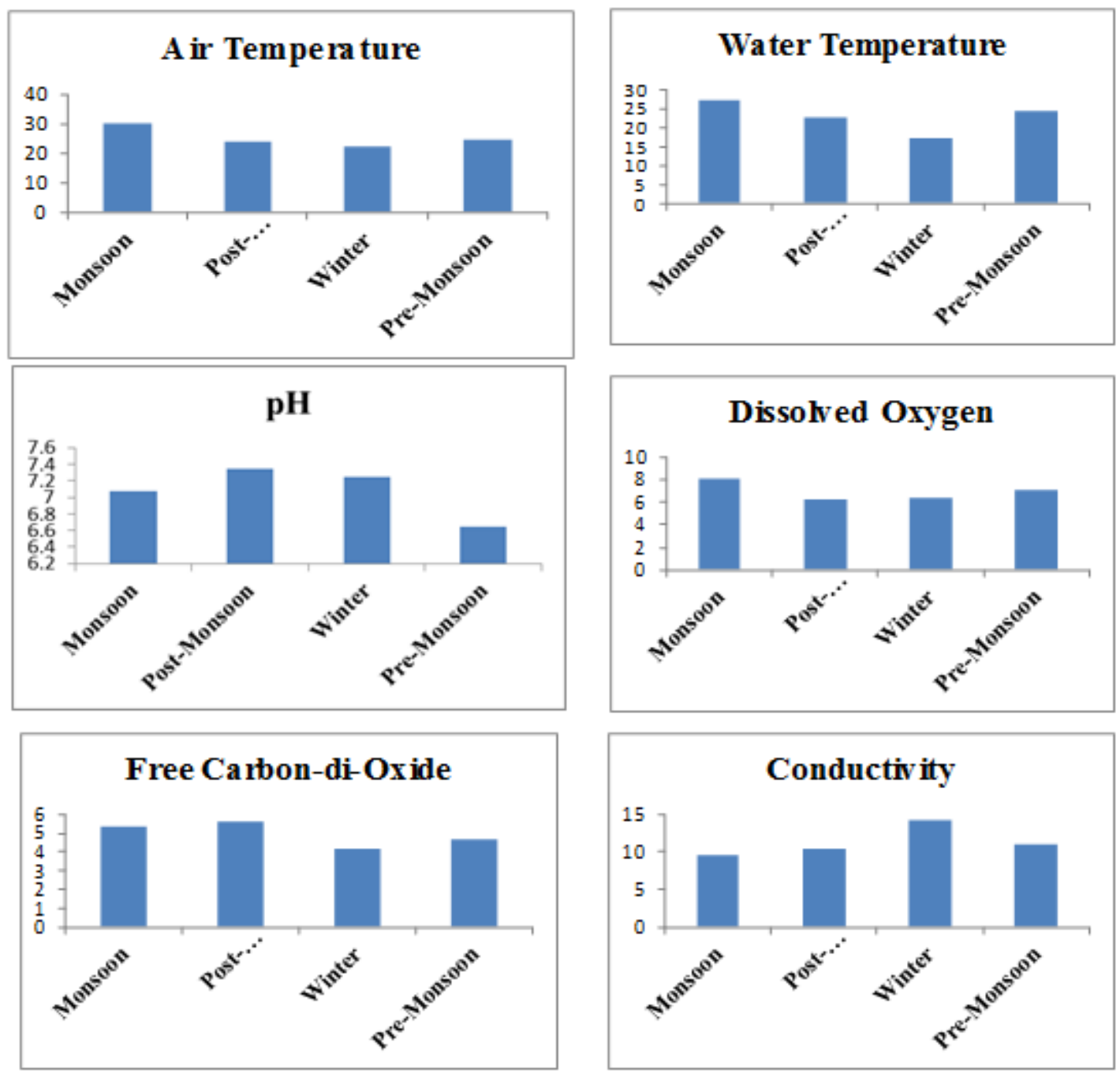

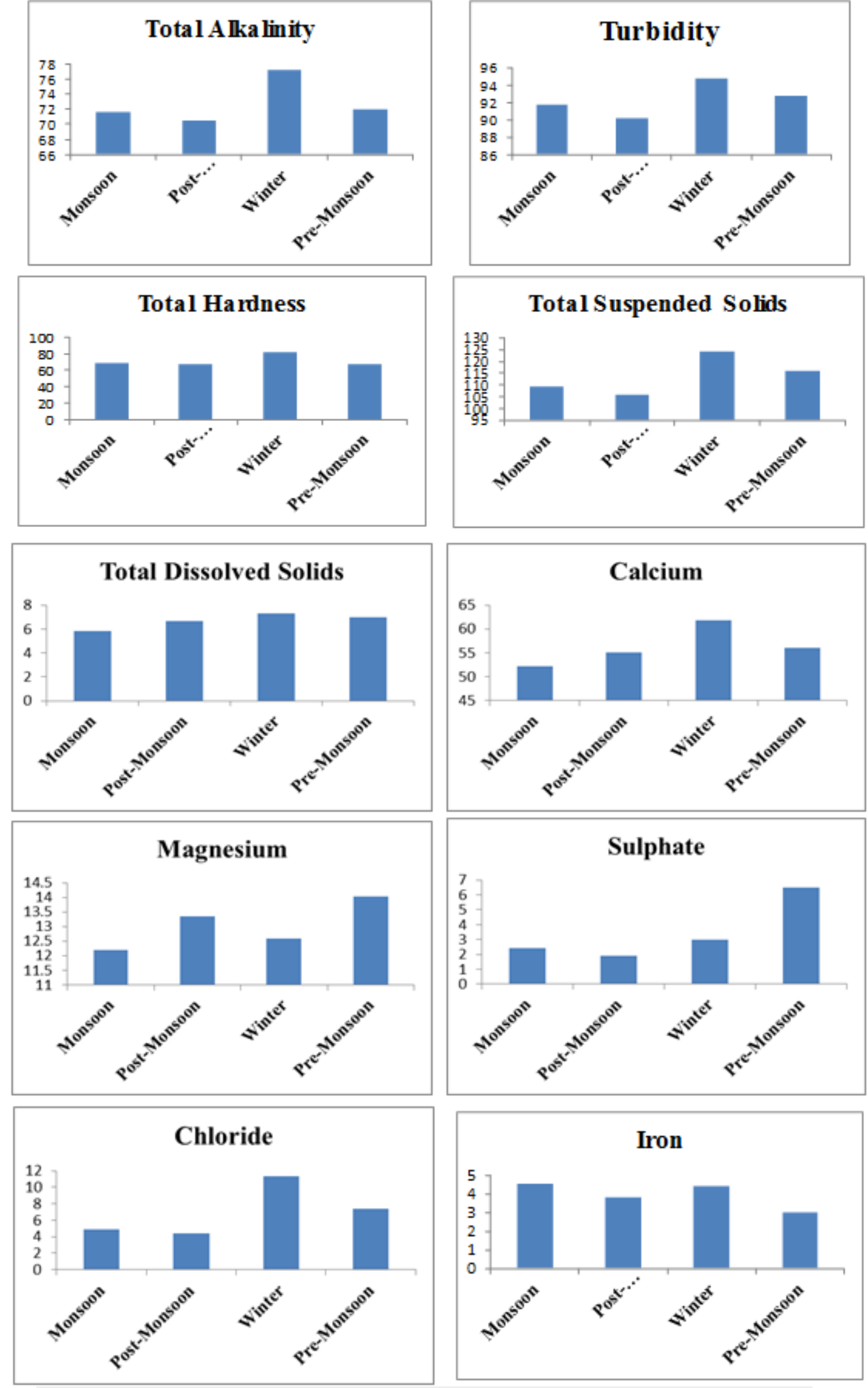


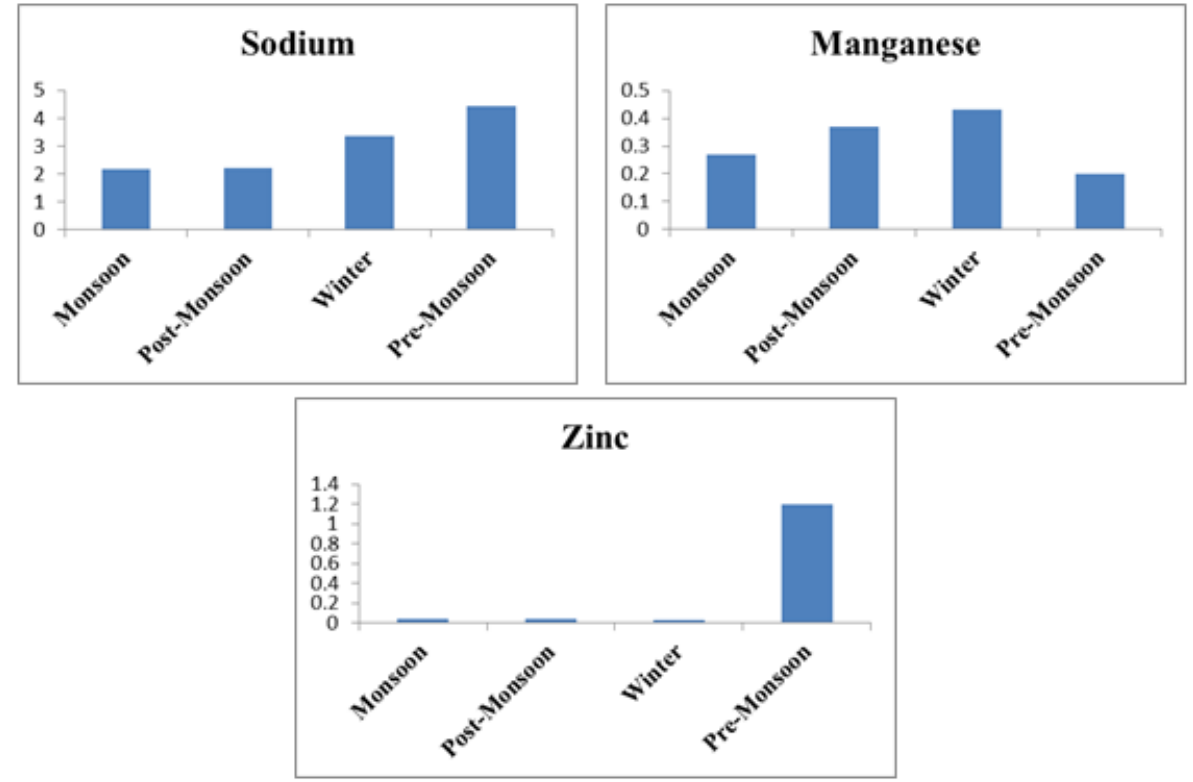

Fig II: Average Physico-Chemical Parameters in Different Seasons

\section{Conclusion}

Physico-chemical characteristics of surface water varied according to seasons. Most of the water parameters vary seasonally. The results showed that mid-stream and downstream of the River Siang i.e. Ranaghat Pasighat, Ponging and Rottang are more polluted than that of upstream and downstream because of the sewage and wastage that comes from the Pasighat town. There is no significance chance in the $\mathrm{pH}$ value during the observation period. There were significant occurrence in Conductivity, TDS and TSS which call for caution on discharge untreated waste into River Siang. The study reveals that the water of River Siang shows seasonal variations in Calcium, Magnesium and Total Hardness which may be attributed to the local climatic conditions and water exchange mechanism. Concentrations of nutrients and like nitrite, phosphates etc. are within permissible limits. The physico-chemical characteristic of River Siang in the study area suggested that here was no harmful chemical contamination. If proper measures are taken for the treatment of sewage before discharge and restrictions are out on various anthropogenic activities upstream, the estuary would remain healthy in the long run.

\section{Acknowledgements}

'The authors are thankful to Assam University, Silchar and to the UGC, New Delhi for granting UGCFellowship to the First author. First author grateful to Analytical Chemistry Division of CSIR- North-East Institute of Science and Technology, Jorhat, Assam for providing laboratory facilities and help in chemical analysis of water sample.

\section{References}

[1]. WHO, World Health Organization, Guideline for Drinking Water Quality, Geneva, 2010.

[2]. Jain, A. K., River Pollution, First Edition, APH Publishing, New Delhi, 2009, 330.

[3]. Das, B. K. and Kar, D., Habitat Mapping, Spatial Analysis to Fish Diversity of River Subansiri during Winter Season in Assam and Arunachal Pradesh (India). Environment and Ecology, 29 (4A), 2011, 1948-1951.

[4]. Das, B. K., Dutta, B., Kar, S., Boruah, P. and Kar, D., Icthyofauna of Subansiri River in Assam and Arunachal Pradesh, India. International Journal of Current Research, 5, (11), 2013, 3314-3317.

[5]. Riedel, G. F., Tvvillims, S. A., Riedel, G. S., Olimour, C. C. andSander, J. G., Temperoal and Spatial Patterns of Trace Elements in the Patuxent River; A whole Watershed approach, Estuaries, 23, 2000, 521-535

[6]. Sileika, A., Lnacke, P., Kutra, S., Gaigals, K. and Berankiene, L., Temporal; and Spatial Variation of Nutrient Levels in the ZNemunus River (Lithuania and Belarus), Environ, Monit. Asses, 122, 2006, 335-354.

[7]. Schaefer, S. C. and Alber, M., Temporal and Spatial Trends in Nitrogen and Phosphorous inputs to the Watershed of the Altamaha River, Georgia, USA, Biochemistry, 86, 2007, 231-249.

[8]. Singh, M. R, Gupta, A. and Beeteswari, Kh., Physico-Chemical Properties of Water Samples from Manipur River System, India, Journal of Applied Science Environmental Management, 14 (4), 2010, 85-89.

[9]. Khatoon, N., Rehman, M. and Khan A. F., Study of Seasonal Varition in the water quality among different Ghats of River Ganga, Kanpur, India, Journal of Environmental Research and Development, 8 (1), 2013, 1-10.

[10]. APHA. American Public Health Association Standard Methods for the Examination of Water and Wastewater, Sixteen Edition, Washington, USA, 2010, 1-10.

[11]. Fakayode, S. O., Impart of Industrial effluent on water quality of the receiving Alero River in Ibadan, Nigeria, Ajeam-Ragee, 10 (1), $2005,1-13$. 
[12]. Wetzel, R. G. and Likens, G. E., Limnological Analysis, Third Edition, Springer-Verlag, New York, 391, 2006.

[13]. Das, B. K., Ghosh, A. and Kar, D., Icthyofaunal Diversity of Simen River in Assam and Arunachal Pradesh, India. International Journal of Current Science and Technology, 1(1), 2013, 55-58.

[14]. Das, H. Ecology of Pagaladia River of Assam with Special reference to its Fisheries, Doctoral Dissertation, Gauhati University, Gauhati, Assam, India, 2013, 1-213.

[15]. Das, B. K., Kar, S. and Kar, D., Studies on Intensity of Cestodes Parasite Infecting Monopterus cuchia in Cachar District, Assam. Biological Forum- An International Journal, 4(2), 2012, 71-74.

[16]. Gawas, A. D., Lokhande, P. B. and Meijawas, H. A., Study of Physico-Chemical Parameters of Surface Water in the Mahad Industrial area., Poll Res., 25 (1), 2006, 109-114.

[17]. Annalakshmi, G. and Amsath, A., Nutrient Status of Arsalar River, A Tributory of Cauvery River at Tanjore District of Tamilnadu, India, Int. Journal of Plant, Animal and Environmental Sciences, 2 (2), 2012, 214-222.

[18]. Mishra, A., Mukharjee, A. and Tripathi, B. D., Seasonal and Temporal Variation in physico-chemical and Bacteriological Characteristics of River Ganga in Varanshi, Int. Journal of Env. Res., 3 (3), 2009, 195-203. 